\title{
Isolation of secondary metabolites from Geranium molle L. with anticancer potential
}

\author{
V.C. Graça ${ }^{\mathrm{a}, \mathrm{b}, \mathrm{c}}$, Ricardo C. Calhelha ${ }^{\mathrm{c}}$, Fernando M. Nunes ${ }^{\mathrm{a}}$, Jérôme Berthet ${ }^{\mathrm{d}}$, \\ Isabel C.F.R. Ferreira ${ }^{\mathrm{c}, *}$, P.F. Santos ${ }^{\mathrm{a}, *}$ \\ ${ }^{a}$ Centro de Química - Vila Real (CQ-VR), Universidade de Trás-os-Montes e Alto Douro, 5001-801 Vila Real, Portugal \\ ${ }^{\mathrm{b}}$ Centre for Research and Technology of Agro-Environmental and Biological Sciences (CITAB) - Vila Real, University of Trás-os-Montes and Alto Douro, 5001-801 Vila \\ Real, Portugal \\ ${ }^{\mathrm{c}}$ Centro de Investigação de Montanha (CIMO), Instituto Politécnico de Bragança, Campus de Santa Apolónia, 5300-253 Bragança, Portugal \\ ${ }^{\mathrm{d}}$ Univ. Lille, CNRS, UMR 8516, LASIR - Laboratoire de Spectrochimie Infra-rouge et Raman, F-59000, Lille, France
}

A R T I C L E I N F O

\section{Keywords:}

Geranium molle L.

Cytotoxic activity

Phenolic compounds

Secondary metabolites

\begin{abstract}
A B S T R A C T
Two flavone glycosides, apigenin-6-C-glucoside (1) and lutelin-6- $C$-glucoside (2), and an anomeric mixture of 2,3-dygalloyl-4,6-HHDP-D-glucose $(\mathbf{3 a / 3 b})$ were isolated for the first time from Geranium molle L., a medicinal plant used in the folk medicine of northeast of Portugal for the treatment of a variety of ailments, including cancer. The cytotoxic activity of the isolated compounds was assessed against several human tumour cell lines and non-tumour porcine liver primary cells. The anomeric mixture of ellagitannins $\mathbf{3 a} \mathbf{a} \mathbf{3} \mathbf{b}$, with the two anomers showing considerably different hydrophobicities, was found to be significantly cytotoxic against cancer cells, with only moderate hepatotoxicity.
\end{abstract}

\section{Introduction}

Since ancient civilizations the products of natural origin have been used in traditional medicines for the prevention or treatment of different ailments. In recent years, phenolic compounds, which are the most abundant secondary metabolites in plants, have been the subject of much interest for being endowed with various bioactivities (CongCong et al., 2017; Visioli et al., 2011). Phenolic compounds act as scavengers of reactive oxygen species and are considered to help reduce the risk of development of many diseases such as atherosclerosis, diabetes, hypertension, cardiovascular and neuro-degenerative diseases and cancer (Cory et al., 2018; Marquardt and Watson, 2014). The different biological activities of phenolic compounds are most likely due to their large structural diversity. The present valorisation of medicinal plants is largely based on the richness of these plants in phenolic compounds (Tungmunnithum et al., 2018).

Geranium molle L. is a plant belonging to the Geraniaceae family and it is distributed throughout the world (Aedo et al., 1998a, 1998b). Despite its widespread distribution, apparently only one ethnopharmacological study refers the use of this plant in folk medicine. Flowering aerial parts and roots of wild G. molle are traditionally used in the northeast of Portugal to prepare decoctions and infusions for the treatment of various disorders, including cancer (Neves et al., 2009).
Unlike many other species from Geranium genus, there seems to exist no reference to its bioactivity or phytochemical composition with the exception of two recent studies disclosed by our group (Graça et al., 2016, 2018). Firstly, we carried out a preliminary assessment of the bioactivity and the determination of the phenolic composition of different aqueous and organic extracts of the plant (Graça et al., 2016). Following this, the fractionation of the two more bioactive extracts acetone and $\mathrm{MeOH}$ - was carried out by gradient elution column chromatography on silica gel (Graça et al., 2018). The antioxidant activity and the cytotoxicity of each fraction against selected human cancer cell lines were assessed and the phenolic profile was determined. The fractionation gave rise to fractions with lower structural complexity, allowing the identification of a greater number of compounds.

The objectives of the present work were the isolation of the major phenolic compounds present in the fractions with the best bioactivity by semipreparative HPLC, their structural characterization and the evaluation of the cytotoxic activity against the same cancer cells lines, in order to accesses the contribution of each compound for the observed cytotoxicity of the bioactive fractions.

\footnotetext{
* Corresponding authors.

E-mail addresses: iferreira@ipb.pt (I.C.F.R. Ferreira), psantos@utad.pt (P.F. Santos).
} 


\section{Materials and methods}

\subsection{General experimental procedures}

Melting points were measured in a melting point apparatus equipped with a binocular microscope (Rotoquímica, Portugal) and are uncorrected. NMR spectra were acquired on Bruker NEO-500 spectrometer $\left({ }^{1} \mathrm{H} 500 \mathrm{MHz},{ }^{13} \mathrm{C} 125 \mathrm{MHz}\right)$ equipped with a TXI probe. Data sets were processed using Bruker Topspin 4.0.2 software. Samples were dissolved in methanol- $d_{4}$ in NMR glass tubes $(5 \mathrm{~mm})$. Chemical shifts are expressed in ppm relative to the residual proton signal in deuterated solvent. Chemical shifts are reported as position ( $\delta$ in ppm), multiplicity, coupling constant $(\mathrm{J}$ in $\mathrm{Hz}$ ), integral. The attributions of protons and carbons were achieved by analysis of 2D experiments (COSY, HSQC and $\mathrm{HMBC}$ ). High resolution electrospray ionization time-of-flight mass spectra (HRMS ESI-TOF) were determined on Apex-Q FT-ICR or micrOTOF mass spectrometers (Bruker, Germany). Semipreparative HPLC separations were conducted on a DIONEX UltiMate 3000 instrument equipped with a RP-C18 (ACE, $5 \mu \mathrm{m}, 250 \mathrm{~mm} \times 10 \mathrm{~mm}$ ) column. Analytical HPLC was performed with a DIONEX UltiMate 3000 instrument equipped with a RP-C18 (ACE, $5 \mu \mathrm{m}, 250 \mathrm{~mm} \times 4.6 \mathrm{~mm}$ ) column. Solvents for HPLC separation were of chromatographic grade.

\subsection{Plant material}

Geranium molle L. was collected in Serra da Nogueira, Bragança, north-eastern Portugal, in March 2015. The botanical identification was confirmed by the agronomist Dra. Ana Maria Carvalho of the School of Agriculture, Instituto Politécnico de Bragança (Trás-os-Montes, Portugal). Voucher specimens (Geranium molle L. ETBO 61 of 30 of March of 2015) are deposited at the herbarium of the Escola Superior Agrária de Bragança (BRESA).

\subsection{Preparation of the fractions}

The starting acetone extract was obtained by sequential extraction of the lyophilized whole plant with different organic solvents ( $n$ hexane, $\mathrm{CH}_{2} \mathrm{Cl}_{2}$, EtOAc, acetone and $\mathrm{MeOH}$ ) as described previously (Graça et al., 2016). The crude acetone extract was then fractionated by gradient elution column chromatography in silica gel using an eluotropic series comprising $\mathrm{CH}_{3} \mathrm{Cl}$, EtOAc, acetone, $\mathrm{MeOH}$ and $\mathrm{HCO}_{2} \mathrm{H}$ to yield 12 fractions (FA1 to FA12) as described (Graça et al., 2018).

\subsection{Isolation of compounds}

Fractions FA4, FA5 and FA6 were separated using semipreparative HPLC. The eluent system was composed by $1 \%$ aqueous $\mathrm{HCO}_{2} \mathrm{H}$ (eluent A) and $\mathrm{MeOH}$ (eluent B) and a flow rate of $1 \mathrm{~mL} / \mathrm{min}$ was used. The elution was performed as follows: $0-130 \mathrm{~min}, 5-65 \% \mathrm{MeOH}$; 130-134 min, 65-5\% MeOH; 134-150 min, 5\% MeOH. The injection volume was $2 \mathrm{~mL}$. A total of 105 sub-fractions of $1.43 \mathrm{~mL}$ each were collected. The purity of each subfraction was confirmed by analytical HPLC, using the eluent mixture and the flow rate described above. The program used was 0-65 min, 5-65\% $\mathrm{MeOH}$; 65-67 min, 65-5\% MeOH; $67-75 \mathrm{~min}, 5 \% \mathrm{MeOH}$. The injection volume was $50 \mu \mathrm{L}$. The subfractions containing the same single compound were combined, concentrated under reduced pressure and lyophilized. Fraction FA4 (1 g) furnished a mixture of 2,3-dygalloyl-4,6-HHDP- $\alpha$-D-glucose (3a) and 2,3-dygalloyl-4,6-HHDP- $\beta$-D-glucose (3b) (50 mg). Fraction FA5 $(400 \mathrm{mg}$ ) yielded apigenin-6-C-glucoside (1) (1 mg) and lutelin-6-Cglucoside (2) (8 mg). Fraction FA6 (500 mg) furnished $2(5 \mathrm{mg})$.

Apigenin-6-C-glucoside (1): Yellow, amorphous powder; M.p. 221-222 ${ }^{\circ} \mathrm{C}$; UV (MeOH) $\lambda_{\max } 213,271,336 \mathrm{~nm} ;{ }^{1} \mathrm{H}$ and ${ }^{13} \mathrm{C}$ NMR data $\left(\mathrm{CD}_{3} \mathrm{OD}\right)$ : Table 1; HRMS (ESI-TOF) $\mathrm{m} / \mathrm{z}: 433.1124\left([\mathrm{M}+\mathrm{H}]^{+}\right.$, calc. for $\mathrm{C}_{21} \mathrm{H}_{21} \mathrm{O}_{10}$ : 433.1129); $\mathrm{m} / z: 455.0936\left([\mathrm{M}+\mathrm{Na}]^{+}\right.$, calc. for $\mathrm{C}_{21} \mathrm{H}_{20} \mathrm{NaO}_{10}$ : 455.0949).
Table 1

${ }^{1} \mathrm{H}$ and ${ }^{13} \mathrm{C}$ NMR data of apigenin-6-C-glucoside (1) and lutelin-6-C-glucoside (2) in $\mathrm{CD}_{3} \mathrm{COD}\left({ }^{1} \mathrm{H} 500 \mathrm{MHz},{ }^{13} \mathrm{C} 125 \mathrm{MHz}\right)^{\mathrm{a}}$.

\begin{tabular}{|c|c|c|c|c|}
\hline \multirow{2}{*}{$\begin{array}{l}\text { Compound } \\
\text { position }\end{array}$} & \multicolumn{2}{|l|}{1} & \multicolumn{2}{|l|}{2} \\
\hline & $\delta \mathrm{C}$, type & $\delta \mathrm{H}(J$ in $\mathrm{Hz})$ & $\delta \mathrm{C}$, type & $\delta \mathrm{H}(J$ in $\mathrm{Hz})$ \\
\hline 2 & 164.8, C & & 164.9, C & \\
\hline 3 & $102.5, \mathrm{CH}$ & 6.64, s & 102.5, CH & $6.57, \mathrm{~s}$ \\
\hline 4 & 182.7, C & & 182.6, C & \\
\hline $4 a$ & 103.8, C & & 103.8, C & \\
\hline 5 & 160.7, C & & $160.6, \mathrm{C}$ & \\
\hline 6 & 107.8, C & & $107.8, \mathrm{C}$ & \\
\hline 7 & $163.6, \mathrm{C}$ & & 163.6, C & \\
\hline 8 & 93.8, CH & $6.54, \mathrm{~s}$ & 93.8, $\mathrm{CH}$ & $6.51, \mathrm{~s}$ \\
\hline $8 \mathrm{a}$ & 157.3, C & & $157.3, \mathrm{C}$ & \\
\hline $1^{\prime}$ & $121.7, \mathrm{C}$ & & $122.1, \mathrm{C}$ & \\
\hline $2^{\prime}$ & 128.1, CH & 7.87, d (8.7) & 112.7, CH & 7.39, br s \\
\hline $3^{\prime}$ & 115.6, CH & $6.95, \mathrm{~d}(8.7)$ & 145.7, C & \\
\hline $4^{\prime}$ & $161.4, \mathrm{C}$ & & $149.7, \mathrm{C}$ & \\
\hline $5^{\prime}$ & 115.6, CH & $6.95, \mathrm{~d}(8.7)$ & $115.4, \mathrm{CH}$ & $6.92, \mathrm{~d}(8.2)$ \\
\hline $6^{\prime}$ & 128.1, CH & $7.87, \mathrm{~d}(8.7)$ & 118.9, CH & 7.40, dd $(1.9,8.2)$ \\
\hline $1^{\prime \prime}$ & $73.9, \mathrm{CH}$ & $4.93, \mathrm{~d}(9.2)$ & $73.9, \mathrm{CH}$ & $4.92, \mathrm{~d}(9.2)$ \\
\hline $2 "$ & $71.1, \mathrm{CH}$ & $\begin{array}{l}4.19 \text {, ddd }(9.2,7.0 \text {, } \\
2.2)\end{array}$ & $71.2, \mathrm{CH}$ & $\begin{array}{l}4.19 \text {, ddd (9.2, 7.0, } \\
2.2)\end{array}$ \\
\hline $3 "$ & 78.7, $\mathrm{CH}$ & $3.50, \mathrm{~m}$ & 78.7, $\mathrm{CH}$ & $3.50, \mathrm{~m}$ \\
\hline $4^{\prime \prime}$ & $70.4, \mathrm{CH}$ & $3.50, \mathrm{~m}$ & $70.4, \mathrm{CH}$ & $3.50, \mathrm{~m}$ \\
\hline 5" & $81.2, \mathrm{CH}$ & $3.44, \mathrm{~m}$ & $81.2, \mathrm{CH}$ & $3.44, \mathrm{~m}$ \\
\hline \multirow[t]{2}{*}{ 6" } & $61.4, \mathrm{CH} 2$ & 3.89 , dd $(1.9,12.1)$ & $61.5, \mathrm{CH} 2$ & 3.90 , dd $(2.2,12.1)$ \\
\hline & & 3.76 , dd $(5.4,12.1)$ & & 3.76 , dd $(5.4,12.1)$ \\
\hline
\end{tabular}

${ }^{\mathrm{a}}$ For atom numbering see Fig. 1.

Luteolin-6-C-glucoside (2): Yellow, amorphous powder; M.p. 242-243 ${ }^{\circ} \mathrm{C}$; UV (MeOH) $\lambda_{\max } 212,270,349 \mathrm{~nm} ;{ }^{1} \mathrm{H}$ NMR and ${ }^{13} \mathrm{C}$ NMR data $\left(\mathrm{CD}_{3} \mathrm{OD}\right)$ : Table 1 ; HRMS (ESI-TOF) $m / z: 449.1077\left([\mathrm{M}+\mathrm{H}]^{+}\right.$, calc. for $\mathrm{C}_{21} \mathrm{H}_{21} \mathrm{O}_{11}$ : 449.1078); $m / z: 471.0899\left([\mathrm{M}+\mathrm{Na}]^{+}\right.$, calc. for $\mathrm{C}_{21} \mathrm{H}_{20} \mathrm{NaO}_{11}$ : 471.0898).

2,3-Dygalloyl-4,6-HHDP- $\alpha$-D-glucose $\quad$ (3a)/2,3-Dygalloyl-4,6HHDP- $\boldsymbol{\beta}$-D-glucose (3b): White powder. UV (MeOH) $\lambda_{\max } 218,276 \mathrm{~nm}$; ${ }^{1} \mathrm{H}$ NMR and ${ }^{13} \mathrm{C}$ NMR data $\left(\mathrm{CD}_{3} \mathrm{OD}\right.$ ): Table 2 ; HRMS (ESI-TOF) $\mathrm{m} / z$ : $787.0993\left([\mathrm{M}+\mathrm{H}]^{+}\right.$, calc. for $\mathrm{C}_{34} \mathrm{H}_{27} \mathrm{O}_{22}$ : 787.0988); m/z: 809.0822 $\left([\mathrm{M}+\mathrm{Na}]^{+}\right.$, calc. for $\left.\mathrm{C}_{34} \mathrm{H}_{26} \mathrm{NaO}_{22}: 809.0808\right)$.

\subsection{Cytotoxicity in human tumour cell lines and hepatotoxicity in non-} tumour cells

Compounds 1-3 were dissolved in $\mathrm{H}_{2} \mathrm{O} / \mathrm{MeOH} 80 / 20$ (v/v) to obtain stock solutions with a concentration of $8 \mathrm{mg} / \mathrm{mL}$. The final solutions, with a range of concentrations from 6.25 to $400 \mu \mathrm{g} / \mathrm{mL}$, were prepared by serial dilution of the stock solutions. In vitro cytotoxicity was evaluated by the Sulforhodamine B (SRB) assay using four human tumour cell lines: MCF-7 (breast adenocarcinoma), NCI-H460 (non-small cell lung cancer), HeLa (cervical carcinoma) and HepG2 (hepatocellular carcinoma), as described elsewhere (Barros et al., 2013; Dias et al., 2013).

The hepatotoxicity was evaluated against non-tumour porcine liver primary cells (PLP2). This cell culture was prepared from freshly harvested porcine liver obtained from a local slaughter house, as described (Barros et al., 2013; Dias et al., 2013). The SRB assay was performed according to the procedure previously described (Barros et al., 2013; Dias et al., 2013). In all cases the results are expressed in $\mathrm{GI}_{50}$ values, which correspond to the concentration that inhibits $50 \%$ of cell growth. Ellipticine was used as standard.

\subsection{Statistical analysis}

All the assays were carried out in duplicate. The results are expressed as mean values and standard deviation. The results were analysed using a Student's t-test to determine the significant difference 
Table 2

${ }^{1} \mathrm{H}$ and ${ }^{13} \mathrm{C}$ NMR data of 2,3-dygalloyl-4,6-HHDP- $\alpha$-D-glucose (3a) and 2,3-dygalloyl-4,6-HHDP- $\beta$-D-glucose $(3 \mathrm{~b})$ in $\mathrm{CD}_{3} \mathrm{COD}\left({ }^{1} \mathrm{H} 500 \mathrm{MHz},{ }^{13} \mathrm{C} 125 \mathrm{MHz}\right)^{\mathrm{a}}$.

\begin{tabular}{|c|c|c|c|c|}
\hline \multirow{2}{*}{$\begin{array}{l}\text { Compound } \\
\text { position }\end{array}$} & \multicolumn{2}{|l|}{$3 \mathbf{a}$} & \multicolumn{2}{|l|}{$3 \mathbf{b}$} \\
\hline & $\delta_{\mathrm{C}}$, type & $\delta_{\mathrm{H}}(J$ in $\mathrm{Hz})$ & $\delta_{\mathrm{C}}$, type & $\delta_{\mathrm{H}}$ \\
\hline 1 & $90.4, \mathrm{CH}$ & $5.51, \mathrm{~d}(3.8)$ & $95.7, \mathrm{CH}$ & $4.99, \mathrm{~d}(8.0)$ \\
\hline 2 & $72.2, \mathrm{CH}$ & $\begin{array}{l}5.12 \text {, dd (3.8, } \\
10.0)\end{array}$ & 73.4, $\mathrm{CH}$ & $\begin{array}{l}5.21 \text {, dd }(8.2, \\
9.6)\end{array}$ \\
\hline 3 & $70.6, \mathrm{CH}$ & $5.86, \mathrm{t}(9.8)$ & $72.9, \mathrm{CH}$ & $5.62, \mathrm{t}(9.8)$ \\
\hline 4 & $70.6, \mathrm{CH}$ & $5.14, \mathrm{t}(10.2)$ & $70.3, \mathrm{CH}$ & $5.17, \mathrm{t}(10.2)$ \\
\hline 5 & $66.2, \mathrm{CH}$ & $\begin{array}{l}4.67 \text {, dd (6.6, } \\
10.2)\end{array}$ & $71.4, \mathrm{CH}$ & $\begin{array}{l}4.23 \text {, dd (6.6, } \\
10.2)\end{array}$ \\
\hline 6 & $62.9, \mathrm{CH}_{2}$ & $\begin{array}{l}\text { 5.34, dd (6.4, } \\
13.1) \\
3.85 \text {, d (13.1) }\end{array}$ & $62.8, \mathrm{CH}_{2}$ & $\begin{array}{l}\text { 5.37, dd (6.4, } \\
13.1) \\
3.93 \text {, d (13.1) }\end{array}$ \\
\hline $1^{\prime}$ & 119.2, C & & 119.2, C & \\
\hline $2^{\prime}$ & $109.0, \mathrm{CH}$ & $7.04, \mathrm{~s}$ & $109.0, \mathrm{CH}$ & $7.02, \mathrm{~s}$ \\
\hline $3^{\prime}$ & $\begin{array}{l}145.0 / 144.8, \\
\text { C }\end{array}$ & & $\begin{array}{l}145.0 / 144.8, \\
\text { C }\end{array}$ & \\
\hline $4^{\prime}$ & $\begin{array}{l}\text { 138.8/138.5, } \\
\text { C }\end{array}$ & & $\begin{array}{l}145.0 / 144.8, \\
\text { C }\end{array}$ & \\
\hline $5^{\prime}$ & $\begin{array}{l}145.0 / 144.8, \\
\text { C }\end{array}$ & & $\begin{array}{l}145.0 / 144.8, \\
\text { C }\end{array}$ & \\
\hline $6^{\prime}$ & 109.0, CH & $7.04, \mathrm{~s}$ & 109.0, CH & $7.02, \mathrm{~s}$ \\
\hline $7^{\prime}$ & 166.1, C & & $165.7, \mathrm{C}$ & \\
\hline $1^{\prime \prime}$ & $119.4, \mathrm{C}$ & & $119.5, \mathrm{C}$ & \\
\hline $2^{\prime \prime}$ & $109.0, \mathrm{CH}$ & $6.95, \mathrm{~s}$ & $109.0, \mathrm{CH}$ & $6.91, \mathrm{~s}$ \\
\hline $3^{\prime \prime}$ & $\begin{array}{l}\text { 145.0/144.8, } \\
\text { C }\end{array}$ & & $\begin{array}{l}145.0 / 144.8, \\
\text { C }\end{array}$ & \\
\hline $4^{\prime \prime}$ & $\begin{array}{l}\text { 138.8/138.5, } \\
\text { C }\end{array}$ & & $\begin{array}{l}\text { 138.8/138.6, } \\
\text { C }\end{array}$ & \\
\hline $5^{\prime \prime}$ & $\begin{array}{l}145.0 / 144.8, \\
\text { C }\end{array}$ & & $\begin{array}{l}145.0 / 144.8, \\
\text { C }\end{array}$ & \\
\hline $6^{\prime \prime}$ & 109.0, CH & $6.95, \mathrm{~s}$ & 109.0, CH & $6.91, \mathrm{~s}$ \\
\hline $7^{\prime \prime}$ & $166.5, \mathrm{C}$ & & $166.3, \mathrm{C}$ & \\
\hline 1'a & 115.0, C & & 115.0, C & \\
\hline $2^{\prime} \mathrm{a}$ & $136.2, \mathrm{C}$ & & 136.2, C & \\
\hline 3'a & $\begin{array}{l}\text { 124.9/124.5, } \\
\text { C }\end{array}$ & & $\begin{array}{l}\text { 124.9/124.5, } \\
\text { C }\end{array}$ & \\
\hline $4^{\prime} \mathrm{a}$ & 144.5, C & & 144.5, C & \\
\hline $5^{\prime} a$ & $143.4, \mathrm{C}$ & & $143.4, \mathrm{C}$ & \\
\hline 6'a & $106.8, \mathrm{CH}$ & $6.52, \mathrm{~s}$ & $106.8, \mathrm{CH}$ & $6.48, \mathrm{~s}$ \\
\hline 7'a & 167.9, C & & $167.8, \mathrm{C}$ & \\
\hline $1 " \mathrm{a}$ & 115.3, C & & 115.3, C & \\
\hline $2 " \mathrm{a}$ & 136.2, C & & 136.2, C & \\
\hline $3 " \mathrm{a}$ & $\begin{array}{l}\text { 124.9/124.5, } \\
\text { C }\end{array}$ & & $\begin{array}{l}\text { 124.9/124.5, } \\
\text { C }\end{array}$ & \\
\hline $4 " \mathrm{a}$ & $144.5, \mathrm{C}$ & & $144.5, \mathrm{C}$ & \\
\hline $5 " \mathrm{a}$ & $143.4, \mathrm{C}$ & & $143.4, \mathrm{C}$ & \\
\hline 6"a & 107.2, CH & $6.64, \mathrm{~s}$ & 107.2, $\mathrm{CH}$ & $6.64, \mathrm{~s}$ \\
\hline $7 " \mathrm{a}$ & $168.4, \mathrm{C}$ & & $168.3 \mathrm{C}$ & \\
\hline
\end{tabular}

${ }^{\text {a }}$ For atom numbering see Fig. 1.

among the different samples, with $\alpha=0.05$, using IBM SPSS Statistics for Windows, version 23.0. (IBM Corp., Armonk, NY, USA).

\section{Results and discussion}

\subsection{Isolation and structural elucidation of the compounds}

The selection of the fractions to be separated was performed following two requirements: on one hand, they should display the best cytotoxic activity amongst the obtained fractions and, on the other, they should be available in amounts that would potentially furnish the compounds to be isolated in manageable amounts. The acetone fractions FA4, FA5 and FA6 previously obtained (Graça et al., 2018) were chosen for complying these two criteria. The separation of these fractions by semipreparative HPLC, using $1 \%$ aqueous formic acid and $\mathrm{MeOH}$, allowed the isolation of two flavone glycosides, apigenin-6-Cglucoside (1) and lutelin-6-C-glucoside (2), and a mixture of the two anomeric forms of 2,3-dygalloyl-4,6-HHDP-D-glucose [2,3-dygalloyl4,6-HHDP- $\alpha$-D-glucose (3a) and 2,3-dygalloyl-4,6-HHDP- $\beta$-D-glucose (3b)] (Fig. 1). This is the first time that these compounds were isolated from G. molle, and, to the best of our knowledge, from a Geranium species.

The full structural elucidation of the isolated compounds was established unequivocally on the basis of the corresponding ${ }^{1} \mathrm{H}$ - and ${ }^{13} \mathrm{C}$ NMR spectra (Tables 1 and 2) together with 2D experiments (HSQC, HMBC and COSY) (Supporting Information).

Apigenin-6-C-glucoside (1): ${ }^{1} \mathrm{H}-{ }^{1} \mathrm{H}$ COSY (Figure 3S) underlined the scalar correlations in the glucose unit: $\mathrm{H}_{1}$ " (anomeric proton at $4.93 \mathrm{ppm})-\mathrm{H}_{2}$ " $(4.19 \mathrm{ppm})-\mathrm{H}_{3}$ " $(3.50 \mathrm{ppm})-\mathrm{H}_{4}$ " $(3.50 \mathrm{ppm})-\mathrm{H}_{5}$ " (3.43 ppm) $-\mathrm{H}_{6}$ " (diastereotopic protons at 3.76 and $3.89 \mathrm{ppm}$ ). The diasterotopic protons $\mathrm{H}_{6}$ " in the methylene group were evidenced in ${ }^{1} \mathrm{H}-{ }^{13} \mathrm{C}$ HSQC by their common correlation with the carbon $\mathrm{C}_{6}$, at $61.4 \mathrm{ppm}$ (Figure 4S). The anomeric proton $\mathrm{H}_{1}$ " presents a coupling constant value ${ }^{3} J_{1 "-2}{ }^{\prime \prime}=9.2 \mathrm{~Hz}$, proving its axial position, and hence the $\beta$-glucose conformation. $\mathrm{H}_{1}$ " is attached to $\mathrm{C}_{1}$ " at $73.9 \mathrm{ppm}$, itself bonded to one carbon of the flavone skeleton, $\mathrm{C}_{6}$ at $107.8 \mathrm{ppm}$. Such junction was showed in ${ }^{1} \mathrm{H}^{13} \mathrm{C}$ HMBC thanks to long-range correlations observed between $\mathrm{H}_{1}$, and $\mathrm{C}_{5}(160.7 \mathrm{ppm})$ and $\mathrm{C}_{7}(163.6 \mathrm{ppm})$, and between $\mathrm{H}_{8}$ at $6.54 \mathrm{ppm}$ (singlet) and $\mathrm{C}_{6}(107.8 \mathrm{ppm})$ and $\mathrm{C}_{4 \mathrm{a}}$ (103.8 ppm). From $\mathrm{C}_{4 \mathrm{a}}, \mathrm{H}_{3}$ was attributed to the singlet at $6.64 \mathrm{ppm}$, itself correlated through three bonds to carbon $\mathrm{C}_{1}$, at $121.7 \mathrm{ppm}$. Finally, the two doublets at $7.87(\mathrm{I}=2 \mathrm{H})$ and $6.95(\mathrm{I}=2 \mathrm{H}) \mathrm{ppm}$ with a coupling constant ${ }^{3} J=8.7 \mathrm{~Hz}$ were assigned to $\mathrm{H}_{2^{\prime} / 6^{\prime}}$, and $\mathrm{H}_{3^{\prime} / 5^{\prime}}$, respectively, of the $p$-hydroxybenzene ring.

Lutelin-6-C-glucoside (2): NMR spectra indicated that the structure of $\mathbf{2}$ is very similar to that of $\mathbf{1}$, with the exception of the benzene ring of the flavone, substituted in 2 with $2 \mathrm{OH}$ groups in 3' and 4' positions. This was evidenced by three signals in the ${ }^{1} \mathrm{H}$ NMR spectrum (Figure 6S): $\mathrm{H}_{2},\left(7.39 \mathrm{ppm}, \mathrm{d},{ }^{4} J_{2^{\prime}-6^{\prime}}=1.9 \mathrm{~Hz}, \mathrm{I}=1 \mathrm{H}\right), \mathrm{H}_{5},(6.92 \mathrm{ppm}, \mathrm{d}$, $\left.{ }^{3} J_{5^{\prime}-6^{\prime}}=8.2 \mathrm{~Hz}, \quad \mathrm{I}=1 \mathrm{H}\right)$ and $\mathrm{H}_{6^{\prime}},\left(7.40 \mathrm{ppm}, \mathrm{dd},{ }^{3} J_{5^{\prime}-6^{\prime}}=8.2 \mathrm{~Hz}\right.$, ${ }^{4} J_{2^{\prime}-6^{\prime}}=1.9 \mathrm{~Hz}, \mathrm{I}=1 \mathrm{H}$ ).

Anomeric isomers of 2,3-dygalloyl-4,6-HHDP-D-glucose (3a/3b): In the ${ }^{1} \mathrm{H}$ spectrum (Figure 11S), two sets of signals could be observed. The major isomer (60\%) is 2,3-dygalloyl-4,6-HHDP- $\alpha$-D-glucose (3a). The $\alpha$ conformation is proved by the coupling constant value ${ }^{3} J=3.8 \mathrm{~Hz}$ measured in the doublet of the anomeric proton $\mathrm{H}_{1}$ at $5.51 \mathrm{ppm}$, which is typical of an equatorial-axial coupling. $\mathrm{H}_{1}$ is attached to carbon $\mathrm{C}_{1}$ at 95.7 ppm, more deshielded than in compounds 1 and 2 , due to its substitution with an hydroxyl function. ${ }^{1} \mathrm{H}_{-}{ }^{1} \mathrm{H}$ COSY (Figure 13S) underlined the correlations in the glucose unit: $\mathrm{H}_{1}(5.51 \mathrm{ppm})-\mathrm{H}_{2}$ (5.12 ppm) - $\mathrm{H}_{3}(5.86 \mathrm{ppm})-\mathrm{H}_{4}(5.14 \mathrm{ppm})-\mathrm{H}_{5}(4.67 \mathrm{ppm})-\mathrm{H}_{6}$ (diastereotopic protons at 3.85 and $5.34 \mathrm{ppm}$, both attached to $\mathrm{C}_{6}$ at $62.9 \mathrm{ppm})$. In the ${ }^{1} \mathrm{H}$ NMR spectrum, two singlets $(\mathrm{I}=1 \mathrm{H})$ were observed at $6.52 \mathrm{ppm}\left(\mathrm{H}_{6^{\prime} \mathrm{a}}\right)$ and at $6.64 \mathrm{ppm}\left(\mathrm{H}_{6}{ }^{\prime \prime}\right)$ for the HHDP moiety and two singlets $(\mathrm{I}=2 \mathrm{H})$ at $7.04 \mathrm{ppm}\left(\mathrm{H}_{2}, 6^{\prime}\right)$ and at $6.95 \mathrm{ppm}\left(\mathrm{H}_{2 "}{ }^{\prime \prime} 6^{\prime \prime}\right)$ for the two galloyl ester groups. A ${ }^{1} \mathrm{H}_{-}{ }^{13} \mathrm{C}$ HMBC experiment (Figure $15 S$ ) allowed to identify the positions of the attachment of HHDP and galloyl ester groups to the glucose unit. Long-range correlations were underlined between $\mathrm{H}_{6}$ "a and $\mathrm{C}_{6} \mathrm{H}_{2}$ and $\mathrm{C}_{7}$ "a at $168.4 \mathrm{ppm}$; between $\mathrm{H}_{6}$ 'a and $\mathrm{H}_{4}$ and $\mathrm{C}_{7}$ 'a at $167.9 \mathrm{ppm}$; between $\mathrm{H}_{2}{ }^{\prime} / 6^{\prime}$, and $\mathrm{H}_{2}$ and $\mathrm{C}_{7}$, at $166.1 \mathrm{ppm}$; and between $\mathrm{H}_{2}$ "/6" and $\mathrm{H}_{3}$ and $\mathrm{C}_{7}$ " at $166.5 \mathrm{ppm}$. Such correlations proved that the HHDP moiety is attached to $\mathrm{C}_{4}$ and $\mathrm{C}_{6}$ while the two galloyl esters are linked to $\mathrm{C}_{2}$ and $\mathrm{C}_{3}$. The minor isomer $(40 \%)$ is the 2,3-dygalloyl-4,6-HHDP- $\beta$-D-glucose (3b). The $\beta$-conformation was identified from the doublet signal of the anomeric proton $\mathrm{H}_{1}$ at $4.99 \mathrm{ppm}$ with a coupling constant ${ }^{3} J_{1-2}=8.0 \mathrm{~Hz}$, characteristic of an axial-axial scalar coupling. Its structural elucidation was obtained according to the same NMR procedure used for $\mathbf{3 a}$.

The two flavone glycosides $\mathbf{1}$ and $\mathbf{2}$, as well as the anomeric mixture of $\mathbf{3} \mathbf{a}$ and $\mathbf{3} \mathbf{b}$ presented high resolution mass spectra in full accordance with the proposed structures.

The attempt to separate the $\mathbf{3} \mathbf{a}$ and $\mathbf{3} \mathbf{b}$ by HPLC resulted in combinations of the same anomers with a composition similar to that of the starting mixture. Most probably the conversion of one anomer into the other occurred under the conditions of the chromatographic separation, 


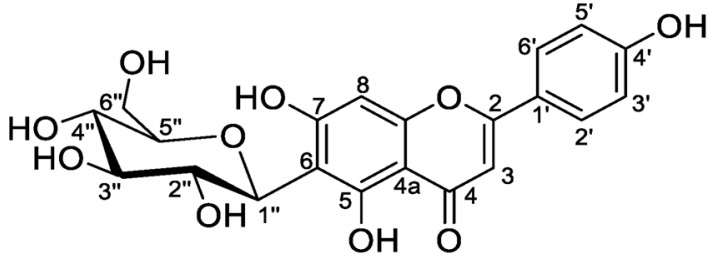

1

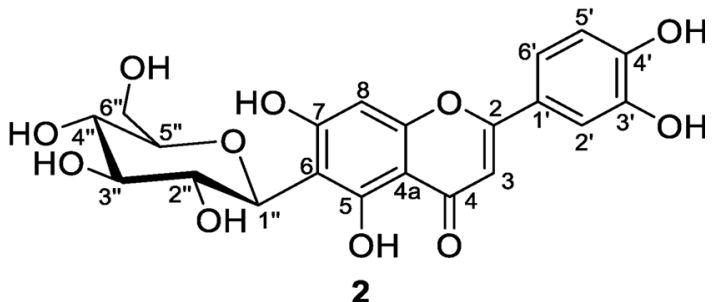

2

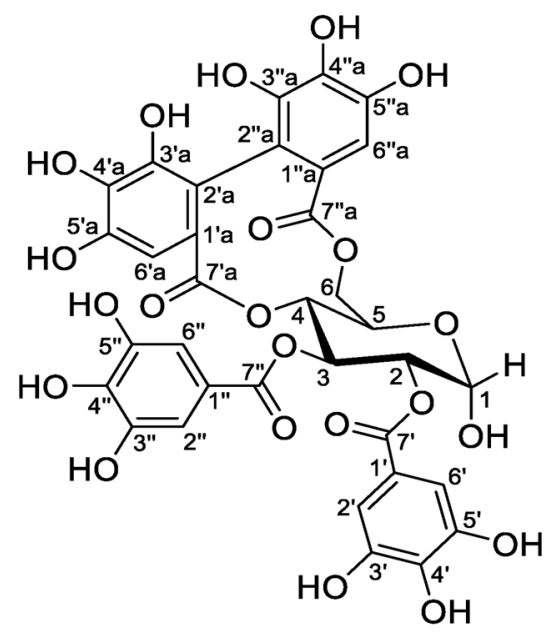

$3 \mathbf{a}$

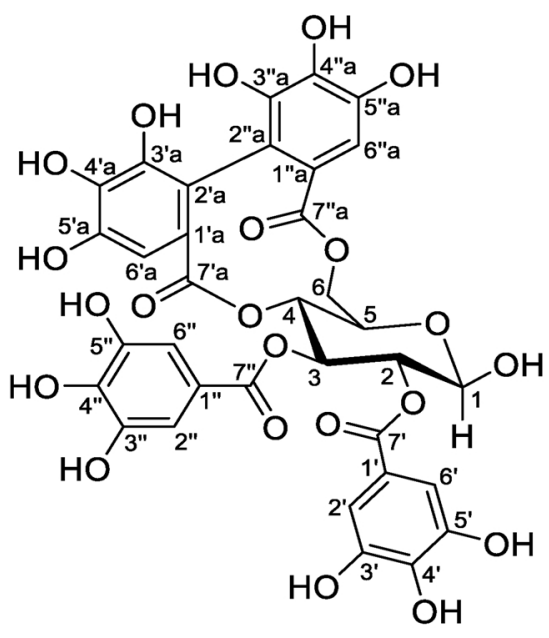

3b

Fig. 1. Metabolites isolated from G. molle.

since anomerization of glycosides is known to easily take place in solution (Tanaka et al., 2018). One interesting observation is the fact that the two anomers showed a substantial difference in their hydrophobicity as they presented very different retention times in the reversed phase column (Valkó et al., 1997), which can have influence in the cytotoxicity of each anomer (Selassie et al., 2005).

\subsection{Evaluation of cytotoxicity of the compounds}

The cytotoxic properties of the compounds isolated from the acetone fractions of $G$. molle were tested against four human tumour cell lines: MCF-7 (breast adenocarcinoma), NCI-H460 (non-small cell lung cancer), HeLa (cervical carcinoma) and HepG2 (hepatocellular carcinoma). The hepatotoxicity was also evaluated using a porcine liver primary cell culture (PLP2). The results are presented in Table 3.

Among the obtained compounds, the mixture of 2,3-digalloyl-4,6-

Table 3

Cytotoxic activity of the compounds isolated from the acetone fractions of $G$. molle L..

\begin{tabular}{llll}
\hline Compound & $\mathbf{1}$ & $\mathbf{2}$ & 3a/3b \\
\hline $\begin{array}{l}\text { Anticancer activity }\left(\mathrm{GI}_{50}, \mu \mathrm{g} /\right. \\
\quad \mathrm{mL})\end{array}$ & & & \\
MCF-7 & $>400$ & $261.67 \pm 0.28 \mathrm{a}$ & $22.32 \pm 0.41 \mathrm{~b}$ \\
NCI-H460 & $>400$ & $298.53 \pm 8.93 \mathrm{a}$ & $56.07 \pm 5.30 \mathrm{~b}$ \\
HeLa & $>400$ & $304.07 \pm 12.03 \mathrm{a}$ & $25.57 \pm 1.16 \mathrm{~b}$ \\
HepG2 & $>400$ & $318 \pm 8.35 \mathrm{a}$ & $61.21 \pm 3.98 \mathrm{c}$ \\
Hepatotoxicity $\left(\mathrm{GI}_{50}, \mu \mathrm{g} / \mathrm{mL}\right)$ & & & $101.53 \pm 3.91 \mathrm{a}$ \\
PLP2 & $>400$ & $>400$ & \\
\hline
\end{tabular}

$\mathrm{GI}_{50}$ values correspond to the sample concentration achieving $50 \%$ of growth inhibition in human tumour cell lines or in liver primary culture PLP2. Ellipticine $\mathrm{GI}_{50}$ values: $1.21 \mu \mathrm{g} / \mathrm{mL}$ (MCF-7), $1.03 \mu \mathrm{g} / \mathrm{mL}$ (NCI-H460), $0.91 \mu \mathrm{g} /$ $\mathrm{mL}$ (HeLa), $1.10 \mu \mathrm{g} / \mathrm{mL}$ (HepG2) and $2.29 \mu \mathrm{g} / \mathrm{mL}$ (PLP2). In each row different letters mean significant differences $(p<0.05)$.
HHDP- $\alpha$-D-glucose (3a) and 2,3-digalloyl-4,6-HHDP- $\beta$-D-glucose (3b) was the one with the best cytotoxic activity against all the tested tumour cell lines. The highest cytotoxic effect was exhibited against MCF7 and HeLa cells $\left(\mathrm{GI}_{50}=22.32\right.$ and $25.57 \mu \mathrm{g} / \mathrm{mL}$, respectively). Conversely, this anomeric mixture also presented the highest toxicity against normal primary cells from porcine liver (PLP2) $\left(\mathrm{GI}_{50}=101.53 \mu \mathrm{g} / \mathrm{mL}\right)$. However, the concentration required to reach $50 \%$ of growth inhibition of PLP2 was, in some cases, about 3-4 times higher than the concentration required to achieve $50 \%$ of growth inhibition of the human tumour cell lines tested. In this way, at the dosage of $61.21 \mu \mathrm{g} / \mathrm{mL}$, the highest $\mathrm{GI}_{50}$ value found, the mixture $3 \mathrm{a} / \mathbf{3 b}$ ensures $50 \%$ of growth inhibition of any of the cancer cell lines tested, without significant hepatotoxic effects. Tellimagrandin I, as it is commonly denoted in the literature the ellagitannin with the 2,3-digalloyl4,6-HHDP-D-glucose structure in the form of an anomeric mixture of undefined proportion or undefined anomeric carbon configuration, has been referred to possess anticancer activity both in vitro (Berdowska et al., 2018; Le et al., 2014; Yi et al., 2006) and in vivo (Miyamoto et al., 1987).

Luteolin-6- $C$-glucoside (2) showed poor to moderate cytotoxic properties, being the highest cytotoxic activity exhibited against the MCF-7 cell line with a $\mathrm{GI}_{50}$ value of $261.67 \mu \mathrm{g} / \mathrm{mL}$. It should be emphasized, however, that this compound did not show significant hepatotoxicity against the PLP2 cell line up to the maximal tested concentration $\left(\mathrm{GI}_{50}>400 \mu \mathrm{g} / \mathrm{mL}\right)$. The antiproliferative properties of luteolin-6-C-glucoside (2) have been previously reported (Conforti et al., 2009; Gundogdu et al., 2018; Huang et al., 2018; Lin et al., 2016; Pacifico et al., 2010; Shoeb et al., 2007; Ye et al., 2016; Yuan et al., 2012, 2013, 2014).

Finally, apigenin-6-C-glucoside (1) showed to be relatively ineffective against all the tested cancer cell lines $\left(\mathrm{GI}_{50}>400 \mu \mathrm{g} / \mathrm{mL}\right)$. Although compound $\mathbf{1}$ did not show cytotoxic activity against the cell lines tested herein within the range of the assayed concentrations, it has demonstrated to possess inhibitory activity against several types of 
cancer cells, as disclosed in a recent review (Ganesan and Xu, 2017).

Comparing the cytotoxicity of the isolated compounds with that of the starting acetone fractions FA4, FA5 and FA6, it is apparent that the cytotoxicity of the mixture $\mathbf{3 a} \mathbf{a} \mathbf{3} \mathbf{b}$ against the tested tumour cell lines ( $\mathrm{GI}_{50}$ values from 22.32 to $61.21 \mu \mathrm{g} / \mathrm{mL}$ ) is similar to that of FA4 $\left(\mathrm{GI}_{50}\right.$ values from 14.5 to $55 \mu \mathrm{g} / \mathrm{mL}$ ), from which it was isolated. Being those the chief compounds of that fraction, it is reasonable to assume that they are the main responsible for the cytotoxic properties displayed by FA4. Contrarily, the cytotoxicity of the two flavone glycosides $\mathbf{1}$ and $\mathbf{2}$ is significantly lower than that of the original acetone fractions FA5 and FA6. In these cases, it seems plausible that a synergistic effect of the mixture of compounds present in each fraction accounts for the higher cytotoxic effect against the human tumour lines in comparison to those of the single compounds.

\section{Conclusions}

Three fractions from G. molle, obtained by the bio-guided fractionation of an acetone extract by gradient elution column chromatography, were subjected to semi-preparative HPLC. This purification process allowed the isolation of two flavone glycosides, apigenin-6-Cglucoside (1) and lutelin-6-C-glucoside (2), and an anomeric mixture of 2,3-dygalloyl-4,6-HHDP-D-glucose (3a/3b), for the first time from G. molle and, to the best of our knowledge, from a Geranium species.

The structural elucidation of the isolated compounds was established unequivocally based on the corresponding 1H- and 13C-NMR spectra, along with 2D experiments (HSQC, HMBC and COSY), and high resolution mass spectra.

Apigenin-6-C-glucoside (1) and luteolin-6-C-glucoside (2) showed poor to moderate cytotoxic properties, while the anomeric mixture of 2,3-digalloyl-4,6-HHDP-D-glucose (3a/3b) exhibited significant cytotoxicity activity against the tested tumour cell lines, with only moderate hepatotoxicity. The highest cytotoxic effect was displayed against MCF7 and HeLa cells.

Unlike the two flavone glycosides $\mathbf{1}$ and $\mathbf{2}$, for which the cytotoxic activity against the cancer cell lines was significantly lower than that of the acetone fractions from which they were isolated, the cytotoxicity of the mixture $\mathbf{3 a} \mathbf{a} \mathbf{3} \mathbf{b}$ was similar to that of the original fraction. This preservation of cytotoxicity suggests that this anomeric mixture of ellagitannins is the main responsible for the cytotoxic properties exhibited by the original fraction.

\section{Declaration of Competing Interest}

None.

\section{Acknowledgements}

This work was supported by European Investment Funds by FEDER/ COMPETE/POCI - Operational Competitiveness and Internationalization Programme, under Project POCI-01-0145-FEDER006958 and National Funds by FCT - Portuguese Foundation for Science and Technology under the projects UID/AGR/00690/2013 (CIMO) and UID/QUI/00616/2013 (CQ-VR). V.C. Graça thanks FCT for her grant (SFRH/BD/52542/2014) and L. Barros for her contract. The authors are also grateful to Interreg España-Portugal for financial support through the project 0377_Iberphenol_6_E.

\section{Appendix A. Supplementary data}

Supplementary material related to this article can be found, in the online version, at doi:https://doi.org/10.1016/j.indcrop.2019.111859.
Batrachioidea and Divaricata (Geraniaceae). Ann. Mo. Bot. Gard. 85, 594-630.

Aedo, C., Garmendia, F.M., Pando, F., 1998b. World checklist of Geranium L. (Geraniaceae). Anales Jard. Bot. Madrid 56, 211-252.

Barros, L., Pereira, E., Calhelha, R.C., Dueñas, M., Carvalho, A.M., Santos-Buelga, C., Ferreira, I.C.F.R., 2013. Bioactivity and chemical characterization in hydrophilic and lipophilic compounds of Chenopodium ambrosioides L. J. Funct. Foods 5, 1732-1740.

Berdowska, I., Zieliński, B., Saczko, J., Sopel, M., Gamian, A., Fecka, I., 2018. Modulatory impact of selected ellagitannins on the viability of human breast cancer cells. J. Funct. Foods 42, 122-128.

Conforti, F., Menichini, F., Rigano, D., Senatore, F., 2009. Antiproliferative activity on human cancer cell lines after treatment with polyphenolic compounds isolated from Iris pseudopumila flowers and rhizomes. Z. Naturforsch 64c, 490-494.

Cong-Cong, X., Bing, W., Yi-Qiong, P., Jian-Sheng, T., Tong, Z., 2017. Advances in extraction and analysis of phenolic compounds from plant materials. Chin. J. Nat. Med. 15, 721-731.

Cory, H., Passarelli, S., Szeto, J., Tamez, M., Mattei, J., 2018. The role of polyphenols in human health and food systems: a mini-review. Front. Nutr. 5, 87.

Dias, M.I., Barros, L., Dueñas, M., Pereira, E., Carvalho, A.M., Alves, R.C., Oliveira, M.B.P.P., Santos-Buelga, C., Ferreira, I.C.F.R., 2013. Chemical composition of wild and commercial Achillea millefolium L. and bioactivity of the methanolic extract, infusion and decoction. Food Chem. 141, 4152-4160.

Ganesan, K., Xu, B., 2017. Molecular targets of vitexin and isovitexin in cancer therapy: a critical review. Ann. N.Y. Acad. Sci. 1401, 102-113.

Graça, V.C., Barros, L., Calhelha, R.C., Dias, M.I., Carvalho, A.M., Santos-Buelga, C., Ferreira, I.C.F.R., Santos, P.F., 2016. Chemical characterization and bioactive properties of Geranium molle L.: from the plant to the most active extract and its phytochemicals. Food Funct. 7, $2204-2212$.

Graça, V.C., Dias, M.I., Barros, L., Calhelha, R.C., Santos, P.F., Ferreira, I.C.F.R., 2018. Fractionation of the more active extracts of Geranium molle L.: a relationship between their phenolic profile and biological activity. Food Funct. 9, 2032-2042.

Gundogdu, G., Dodurga, Y., Elmas, L., Tasci, S.Y., Karaoglan, E.S., 2018. Investigation of the anticancer mechanism of isoorientin isolated from Eremurus spectabilis leaves via cell cycle pathways in HT-29 human colorectal adenocarcinoma cells. Eurasian J. Med. 50, 168-172.

Huang, D., Jin, L., Li, Z., Wu, J., Zhang, N., Zhou, D., Ni, X., Hou, T., 2018. Isoorientin triggers apoptosis of hepatoblastoma by inducing DNA double-strand breaks and suppressing homologous recombination repair. Biomed. Pharmacother. 101, 719-728.

Le, V., Esposito, D., Grace, M.H., Ha, D., Pham, A., Bortolazzo, A., Bevens, Z., Kim, J., Okuda, R., Komarnytsky, S., Ann Lila, M.A., White, J.B., 2014. Cytotoxic effects of ellagitannins isolated from walnuts in human cancer cells. Nutr. Cancer 66, 1304-1314.

Lin, X., Wei, J., Chen, Y., He, P., Lin, J., Tan, S., Nie, J., Lu, S., He, M., Lu, Z., Huang, Q., 2016. Isoorientin from Gypsophila elegans induces apoptosis in liver cancer cells via mitochondrial-mediated pathway. J. Ethnopharmacol. 187, 187-194.

Marquardt, K.C., Watson, R.R., 2014. Polyphenols and public health. In: In: Watson, R.R., Preedy, V.R., Zibadi, S. (Eds.), Polyphenols in Human Health and Disease 1. Elsevier, London, pp. 9-15.

Miyamoto, K., Kishi, N., Koshiura, R., Yoshida, T., Hatano, T., Okuda, T., 1987. Relationship between the structures and the antitumor activities of tannins. Chem. Pharm. Bull. 35, $814-822$.

Neves, J.M., Matos, C., Moutinho, C., Queiroz, G., Gomes, L.R., 2009. Ethnopharmacological notes about ancient uses of medicinal plants in Trás-os-Montes (northern of Portugal). J. Ethnopharmacol. 124, 270-283.

Pacifico, S., Scognamiglio, M., D’Abrosca, B., Piccolella, S., Tsafantakis, N., Gallicchio, M. Ricci, A., Fiorentino, A., 2010. Spectroscopic characterization and antiproliferative activity on HepG2 human hepatoblastoma cells of flavonoid C-glycosides from Petrorhagia velutina. J. Nat. Prod. 73, 1973-1978.

Selassie, C.D., Kapur, S., Verma, R.P., Rosario, M., 2005. Cellular apoptosis and cytotoxicity of phenolic compounds: a quantitative structure-activity relationship study. J. Med. Chem 48, 7234-7242.

Shoeb, M., Jaspars, M., MacManus, S.M., Celik, S., Nahar, L., Kong-Thoo-Lin, P., Sarker, S.D., 2007. Anti-colon cancer potential of phenolic compounds from the aerial parts of Centaurea gigantea (Asteraceae). J. Nat. Med. 61, 164-169.

Tanaka, S., Kojić, D., Tsenkov, R., Yasui, M., 2018. Quantification of anomeric structural changes of glucose solutions using near-infrared spectra. Carbohydr. Res. 463, 40-46.

Tungmunnithum, D., Thongboonyou, A., Pholboon, A., Yangsabai, A., 2018. Flavonoids and other phenolic compounds from medicinal plants for pharmaceutical and medical aspects: an overview. Medicines 5, 93.

Valkó, K., Bevan, C., Reynolds, D., 1997. Chromatographic hydrophobicity index by fast-gradient RP-HPLC: a high-throughput alternative to $\log$ P/log D. Anal. Chem. 69, 2022-2029.

Visioli, F., Lastra, C.A., Andres-Lacueva, C., Aviram, M., Calhau, C., Cassano, A., D’Archivio, M., Faria, A., Gaëlle, F., Fogliano, V., Llorach, R., Vitaglione, P., Zoratti, M., Edeas, M., 2011. Polyphenols and human health: a prospectus. Crit. Rev. Food Sci. Nutr. 51, 524-546.

Ye, T., Su, J., Huang, C., Yu, D., Dai, S., Huang, X., Bicheng Chen, B., Zhou, M., 2016. Isoorientin induces apoptosis, decreases invasiveness, and downregulates VEGF secretion by activating AMPK signaling in pancreatic cancer cells. Onco Targets Ther. 9, 7481-7492.

Yi, Z.C., Liu, Y.Z., Li, H.X., Yin, Y., Zhuang, F.Y., Fan, Y.B., Wang, Z., 2006. Tellimagrandin I enhances gap junctional communication and attenuates the tumor phenotype of human cervical carcinoma HeLa cells in vitro. Cancer Lett. 242, 77-87.

Yuan, L., Wang, J., Xiao, H., Xiao, C., Wang, Y., Liu, X., 2012. Isoorientin induces apoptosis through mitochondrial dysfunction and inhibition of PI3K/Akt signaling pathway in HepG2 cancer cells. Toxicol. Appl. Pharmacol. 265, 83-92.

Yuan, L., Wang, J., Xiao, H., Wu, W., Wang, Y., Liu, X., 2013. MAPK signaling pathways regulate mitochondrial-mediated apoptosis induced by isoorientin in human hepatoblastoma cancer cells. Food Chem. Toxicol. 53, 62-68.

Yuan, L., Wei, S., Wang, J., Liu, X., 2014. Isoorientin induces apoptosis and autophagy simultaneously by reactive oxygen species (ROS)-related p53, PI3K/Akt, JNK, and p38 signaling pathways in HepG2 cancer cells. J. Agric. Food Chem. 62, 5390-5400.

\section{References}

